\title{
Pengembangan Desain Didaktis Materi Pecahan pada Sekolah Menengah Pertama (SMP)
}

\author{
Jaky Jerson Palpialy dan Elah Nurlaelah \\ Program Studi Pendidikan Matematika SPS UPI Bandung \\ Jl. Dr. Setiabudhi No. 229, Bandung 40154 \\ Email: jpalpialy@yahoo.com
}

\begin{abstract}
ABSTRAK
Penelitian ini bertujuan mengembangkan desain didaktis materi pecahan di SMP. Desain didaktis dikembangkan dengan terlebih dahulu mengidentifikasi hambatan belajar (learning obstacles) yang dihadapi siswa. Penelitian menggunakan pendekatan kualitatif, dengan mengikuti tiga tahap pada penelitian desain didaktis (Didactical Design Research). Subyek penelitian adalah 60 siswa kelas VII dan VIII tahun pelajaran 2014/2015 dan 35 siswa kelas VII tahun pelajaran 2015/2016, pada salah satu SMP Negeri di Kabupaten Halmahera Utara. Dari hasil penelitian diperoleh informasi: (1) hambatan belajar siswa yang teridentifikasi, seperti melakukan generalisasi konsep bilangan cacah dan bilangan bulat pada konsep pecahan, dan pengetahuan tentang operasi hitung pecahan yang terbatas pada pemahaman prosedural; (2) desain didaktis empirik terkait materi pecahan di SMP.
\end{abstract}

Kata kunci: Desain didaktis, Learning obstacles, pecahan.

\section{Pendahuluan}

Salah satu topik dalam matematika yang tergolong sulit dipelajari siswa adalah bilangan pecahan. Dalam laporan yang dipublikasikan oleh UNESCO (2010), yang memuat temuan NCTM pada tahun 2007 tentang pembelajaran pecahan, mengemukakan bahwa siswa di seluruh dunia mengalami kesulitan dalam mempelajari pecahan. Di banyak negara, rata-rata siswa tidak pernah memperoleh pengetahuan konseptual yang baik tentang pecahan. Sebagai contoh pada ujian nasional di Amerika, hanya 50\% siswa kelas 8 yang dapat mengurutkan tiga pecahan dengan benar, dari nilai yang terkecil sampai terbesar (Fazio \& Siegler, 2010). Fazio dan Siegler mengemukakan pula bahwa Negara-negara seperti Cina dan Jepang, pecahan dianggap sebagai topik yang sulit.

Salah satu alasan kesulitan yang dihadapi dalam mempelajari pecahan adalah bahwa banyak sifat-sifat yang berlaku pada bilangan bulat tidak berlaku untuk semua bilangan. Misalnya, dengan pecahan, perkalian tidak selalu menghasilkan bilangan yang lebih besar dari bilangan yang dikalikan, pembagian tidak selalu mengarah pada bilangan yang lebih kecil dari bilangan yang dibagi. Salah satu contoh yang pernah diungkapkan oleh Noura (2009), pemahaman siswa sebelumnya bahwa perkalian adalah penjumlahan berulang : $2 \times \frac{1}{2}=\frac{1}{2}+\frac{1}{2}=1$ dan $2 \times \frac{1}{3}=\frac{1}{3}+\frac{1}{3}=\frac{2}{3}$, tetapi pemahaman ini membawa kesulitan bagi mereka dalam menerjemahkan dan menguraikan $\frac{1}{2} \times \frac{1}{2}$ atau $\frac{1}{3} \times \frac{1}{3}$ dengan menggunakan strategi yang sama. Mereka membutuhkan strategi yang lain untuk menjelaskan perkalian pecahan.

Di Indonesia, siswa telah mempelajari pecahan sejak di Sekolah Dasar, namun pada kenyataannya dalam mempelajari pecahan lanjutan di Sekolah Menengah Pertama, banyak siswa yang belum memiliki pemahaman yang baik terhadap pecahan. Hal ini mengakibatkan siswa mengalami kesulitan dalam mempelajari pecahan lebih lanjut, terutama menyelesaikan masalah dalam bentuk soal cerita dan masalah yang berkaitan dengan pecahan dalam mata pelajaran yang lain. Bahkan pemahaman siswa yang kurang terhadap pecahan dapat menjadi salah satu penyebab rendahnya pencapaian mereka dalam materi pecahan di tingkat Sekolah Menengah Pertama. Kesulitan siswa dalam mempelajari materi pecahan di Sekolah Dasar maupun di Sekolah Menengah Pertama, telah dikemukakan oleh beberapa peneliti terdahulu yang meneliti tentang kesulitan belajar matematika yang dialami oleh siswa, bahkan dalam penelitian pendidikan matematika yang berkaitan dengan materi pecahan. Dalam penelitian-penelitian yang dilakukan tersebut, kesulitan-kesulitan siswa dalam mempelajari pecahan diidentifikasi sebagai wujud dari hambatan belajar (Learning Obstacles) yang dialami siswa. 
Menanggapi kesulitan yang dihadapi siswa dalam pembelajaran, para guru cenderung memaknainya sebagai suatu akibat dari upaya siswa yang belum maksimal dalam belajar atau merupakan keterbatasan siswa dalam mempelajari materi ajar. Sementara, kesulitan yang dialami siswa sebenarnya merupakan akibat dari sebuah proses pembelajaran yang didalamnya terdapat interaksi antara guru, siswa, dan materi ajar (Suryadi, 2010). Kesulitan yang dihadapi siswa dalam belajar sebenarnya bukan akibat dari siswa itu sendiri, tetapi dapat saja bersumber dari cara guru dalam menyajikan materi ataupun materi ajar yang digunakan pada saat pembelajaran terjadi. Hal itu diungkapkan oleh Bachelard dan Piaget (Brousseau, 1997), bahwa kesulitan-kesulitan yang dihadapi siswa bukan hanya karena keterlambatan dan perubahan seperti yang diungkapkan oleh pandangan empirisme dan behaviorisme, tetapi juga akibat dari pengetahuan terdahulu yang dianggap tepat namun sekarang terungkap sebagai sesuatu yang salah ataupun tidak berlaku pada konteks sekarang. Dari gagasan inilah kemudian dikemukakannya istilah Learning Obstacles (hambatan belajar). Gagasan tentang Learning Obstacles memandang bahwa kesulitan yang dialami oleh siswa dapat disebabkan dari beberapa sumber, diantaranya guru, materi ajar, dan siswa itu sendiri.

Oleh karena itu, jika dalam desain pembelajaran yang dikembangkan guru sudah dapat mengantisipasi kemungkinan munculnya hambatan belajar, maka hasilnya tentu akan lebih baik. Dalam mengembangkan pembelajaran menurut Suryadi (2010), guru harus berpikir reflektif. Berpikir reflektif dapat dilakukan dalam tiga tahapan (fase) yaitu: (1) sebelum pembelajaran (reflection for action), (2) pada saat proses pembelajaran (reflection in action), dan (3) setelah pembelajaran (reflection of action). Jika proses berpikir reflektif seperti yang dikemukakan di atas dapat dikembangkan dengan baik, maka hasilnya dapat berpotensi menghasilkan desain didaktis baru yang inovatif. Dan rangkaian aktivitas tersebut selanjutnya diformulasikan sebagai penelitian desain didaktis atau Didactical Desing Research (DDR) (Suryadi,2010). Penelitian ini bertujuan untuk mengembangkan desain didaktis materi pecahan dengan mengikuti tahapan penelitian DDR. Pengembanagan desain didaktis mengacu pada teori situasi didaktis (Theory of Didactical Situations in Mathematics) yang dikemukakan oleh Brousseau (1997).

\section{Metode Penelitian}

Penelitian ini menggunakan pendekatan kualitatif, yaitu sebuah pendekatan penelitian yang melakukan analisis data berdasarkan fakta-fakta yang ditemukan di lapangan dan kemudian dikonstruksikan menjadi hipotesis, teori, atau interpretasi (Putra, 2012; Sugiyono, 2013). Proses pengolahan data lebih menekankan pada kajian interpretativ. Kajian tersebut digunakan untuk mengidentifikasi hambatan belajar (learning obstacles) yang dialami subyek terkait materi pecahan. Kemudian disusun desain didaktis yang diupayakan untuk mengantisipasi karakteristik-karakteristik hambatan belajar hasil temuan tersebut. Dengan demikian maka metode yang lebih spesifik yang digunakan dalam penelitian ini adalah Penelitian Desain Didaktis (Didactical Design Research).

Subyek pada penelitian ini adalah siswa SMP Negeri 1 Halmahera Utara, Kabupaten Halmahera Utara, Propinsi Maluku Utara, yang berjumlah 93 orang. Selain siswa, juga guru matematika yang mengajar di sekolah tersebut, sebanyak 3 orang, menjadi subyek penelitian. Subyek penelitian dibagi dalam dua bagian, sesuai tahapan penelitian : pertama, subyek penelitian pendahuluan untuk mengidentifikasi hambatan belajar terkait materi pecahan di SMP, maka dipilih siswa kelas VII dan VIII tahun pelajaran 2014-2015 sebanyak 60 orang. Subyek pada bagian pertama ini juga adalah guru matematika yang mengajarkan materi pecahan ketika siswa berada pada semester ganjil di kelas VII SMP, karena materi pecahan diberikan pada semester tersebut. Kedua, subyek pada tahapan implementasi desain didaktis materi pecahan, yaitu siswa kelas VII tahun pelajaran 20152016, yang berjumlah 33 orang.

Teknik analisis data yang digunakan dalam penelitian ini adalah mengikuti teknik analisis data yang dikemukakan oleh Miles dan Huberman (1984), dengan mengikuti tahapan-tahapan berikut : data reduction, data display, dan conclusion drawing/verivication (Sugiyono, 2013). 


\section{Hasil dan Pembahasan}

\subsection{Analisis Situasi Didaktis Sebelum Pembelajaran}

Analisis situasi didaktis sebelum pembelajaran diawali dengan menganalisis literatur terkait materi pecahan. Analisis dilakukan terhadap kurikulum matematika di tingkat Sekolah Dasar (SD) dan Sekolah Menengah Pertama (SMP), serta bahan ajar yang berupa buku dan LKS yang digunakan oleh guru. Kegiatan ini dilakukan dengan tujuan untuk menghasilkan sebuah desain didaktis hipotetik yang mengacu pada hasil analisis materi ajar, hasil identifikasi hambatan belajar dan kajian repersonalisasi terhadap materi ajar. Hasil kajian literatur dan bahan ajar memberikan masukan yang berarti dalam penyusunan instrumen tes untuk mengidentifikasi hambatan belajar, dan dalam penyusunan desain didaktis hipotetik. Langkah selanjutnya adalah mengembangkan istrumen tes untuk mengidentifikasi hambatan belajar.

Tes untuk mengidentifikasi kemampuan siswa setelah mempelajari pecahan dan kemungkinan adanya hambatan belajar dalam memahami materi pecahan di SMP, menggunakan instrument tes yang disusun dan telah dilakukan validasi teoritik. Jumlah soal tes 8 item dengan durasi waktu 80 menit ( 2 x Jam Pelajaran). Tes dilaksanakan pada 60 siswa, yaitu kelas VII sebanyak 28 siswa dan kelas VIII sebanyak 32 siswa. Jawaban siswa terhadap soal tes yang diberikan, dianalisis dengan memperhatikan kesalahan yang dibuat siswa dalam menjawab soal. Kesalahan siswa tersebut dapat dikategotikan dalam lima tipe yang dominan, yaitu :

1. Kesalahan dalam menentukan kelipatan persekutuan terkecil (KPK) dari beberapa bilangan, dimana konsep KPK merupakan salah satu materi prasyarat mempelajari pecahan.

2. Mengurutkan pecahan dengan membandingkan besar kecilnya penyebut atau pembilang, ketika pembilang atau penyebut tidak disamakan.

3. Menjumlahkan dan mengurangkan pembilang dengan pembilang, penyebut dengan penyebut

4. Siswa mengubah pecahan menjadi pecahan yang berpenyebut sama kemudian melakukan perkalian atau pembagian untuk pembilangnya

5. Kesalahan dalam memilih dan menggunakan operasi hitung pecahan untuk menyelesaikan masalah kontekstual yang berkaitan dengan pecahan.

Berdasarkan analisis hasil tes kemampuan siswa pada materi pecahan, analisis desain bahan ajar pada buku teks siswa, dan analisis desain bahan ajar yang dibuat guru, maka dapat diidentifikasi hambatan belajar yang dialami siswa sebagai berikut :

\section{Hambatan Epistemologi (epistemological obstacles)}

Siswa mengalami epistemological obstacles yaitu ketika melakukan generalisasi konsep bilangan cacah dan bilangan bulat pada konsep pecahan. Hambatan ini teridentifikasi dalam beberapa kesalahan yang dilakukan siswa dalam menjawab soal-soal yang diberikan. Pemahaman siswa tentang bilangan cacah dan bilangan bulat yang telah mereka miliki mempengaruhi mereka ketika mempelajari pecahan. Hal tersebut dapat dilihat pada saat siswa melakukan pengoperasian pada pecahan. Kesalahan siswa yang dapat dikategorikan dalam hambatan ini terdapat pada kesalahan tipe 2, tipe 3 dan tipe 4.

\section{Hambatan Didaktikal (Didactical Obstacles)}

Siswa mengalami didactical obstacles dalam mempelajari pecahan yang teridentifikasi lewat kesalahan yang dilakukan saat mengerjakan soal dan desain bahan ajar yang digunakan guru. Pada soal tes kemampuan pecahan yang diberikan, siswa mengalami kesulitan paling banyak adalah ketika mengerjakan soal-soal penerapan pecahan dalam masalah kehidupan sehari-hari, yaitu pada soal nomor 4 sampai soal nomor 8. Dimana pada soal tersebut menuntut kemampuan siswa untuk mengaplikasikan konsep pecahan yang mereka pahami. Keterbatasan siswa untuk menjawab soal-soal penerapan pecahan disebabkan pengetahuan mereka tentang operasi pecahan yang terbatas pada pemahaman prosedural. Mereka memahami penjumlahan, pengurangan, perkalian dan pembagian pecahan hanya sebatas menjalankan aturan yang telah diajarkan tanpa memahami maksud dari pengerjaan tersebut. Penyebab 
hambatan yang dialami siswa tersebut juga dapat teridentifikasi pada bahan ajar yang digunakan siswa dalam bentuk buku teks dan desain pembelajaran yang digunakan dalam pembelajaran. Buku teks dan desain yang digunakan guru dalam pebelajaran, cenderung menekankan aspek prosedural. Secara khusus untuk operasi hitung pecahan, penekanan guru lebih banyak pada algoritma dan prosedur yang harus dilakukan siswa ketika melakukan sebuah operasi hitung pada pecahan. Akibatnya, siswa dapat melakukan sebuah operasi hitung tetapi gagal menerapkannya dalam menyelesaikan masalah sehari-hari yang berkaitan dengan operasi hitung pecahan

Pengembangan Desain didaktis hipotetik didasarkan pada hasil analisis learning obstacles yang dilakukan pada tahapan sebelumnya. Mengacu pada tujuan yang diharapkan untuk dicapai oleh siswa SMP dalam mempelajari pecahan, dan hambatan belajar yang dialami siswa, maka desain didaktis disusun dengan mengikuti dugaan lintasan belajar (learning trajectories) yang digambarkan sebagai berikut :

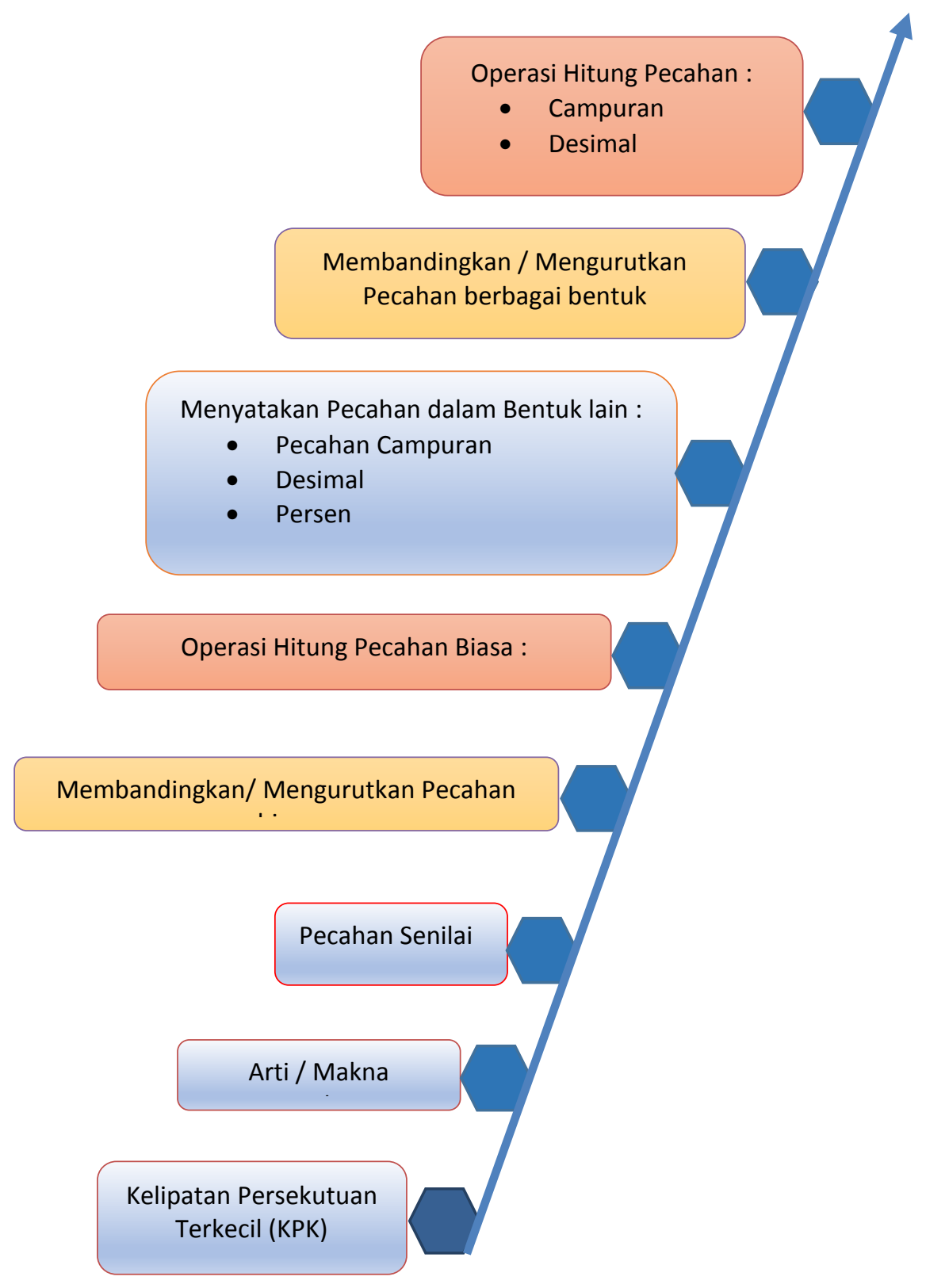

Gambar. 1 Learning Trajectory materi Pecahan SMP

Desain didaktis hipotetik dibagi dalam enam pertemuan dengan 13 situasi didaktis yang dikembangkan. Setiap situasi didaktis dimulai dengan Aksi, Formulasi, Validasi, dan berakhir pada tahap Institusionalisasi. 


\title{
3.2 Pengembangan Desain Didaktis Empirik
}

Tahapan penelitian selanjutnya adalah Analisis metapedadidaktik dan Analisis Retrosfektif yang menghasilkan Desain Didaktis Empirik. Analisis Metapedadidaktik dimulai dengan melakukan implementasi desain didaktis yang telah disusun kemudian menganalisis aktivitas pembelajaran yang dilakukan. Analisis difokuskan pada respon siswa terhadap situasi didaktis yang dirancang, serta antisipasi didaktis terhadap respon yang diberikan siswa. Implementasi desain didaktis dilakukan pada siswa kelas VII di SMP Negeri 1 Halmahera Utara. Kelas yang terpilih sesuai dengan kesepakatan antara peneliti dengan pihak sekolah adalah kelas VII-1 yang berjumlah 35 siswa. Peneliti menggunakan alat perekam video dan suara berupa kamera digital sederhana untuk merekam proses pembelajaran dalam kelas pada saat implementasi desain. Dalam pengambilan video, peneliti dibantu oleh seorang siswa kelas yang lain sebagai kameraman.

Hasil analisis metapedadidaktik kemudian dilakukan analisis retrosfektif, yang mengaitkan hasil pengembangan desain didaktis hipotetik dengan hasil analisis metapedadidaktik. Tahapan analisis retrosfektif berakhir pada pengembangan situasi didaktis revisi sebagai perbaikan dari desain didaktis yang telah diimplementasikan. Berikut disajikan garis besar setiap situasi didaktis pada desain didaktis empirik dengan menampilkan situasi Aksi.

\section{Pertemuan Pertama}

\section{Situasi Satu}

Situasi ini didesain untuk mengingatkan siswa pada materi prasyarat dalam mempelajari pecahan, yaitu : kelipatan persekutuan terkecil (KPK).

\section{Aksi:}

Andi, Beni, dan Dita akan mengisi kotak mereka masing-masing dengan kelereng. Kelereng diambil dari kotak besar yang berisi banyak kelereng. Andi mengambil 2 kelereng, Beni mengambil 3 kelereng dan Dita mengambil 8 kelereng setiap kali mengisi kotak masing-masing. Pengambilan dilakukan berkali-kali dengan jumlah yang tetap sama.

a. Catatlah pertambahan jumlah kelereng dalam kotak masing-masing anak pada setiap pengambilan yang dilakukan, sehingga diperoleh jumlah kelereng yang sama pada ketiga kotak.

b. Apakah dapat terjadi jumlah kelereng dalam ketiga kotak itu sama? Jika dapat, sebutkan jumlah tersebut.

c. Dari beberapa kemungkinan jumlah kelereng yang sama pada ketiga kotak itu, berapakah jumlah yang paling kecil?

\section{Situasi dua}

Situasi dua dirancang untuk mengingatkan kembali arti/makna serta nilai sebuah pecahan biasa, dimana siswa telah mempelajarinya pada jenjang sekolah Dasar.

\begin{abstract}
Aksi :
Siswa ditantang untuk bermain game :'Menebak isi Kotak". Sebagai permulaan, permainan dilakukan oleh guru melawan seluruh siswa. Guru sebagai "Pembuat pertanyaan" dan siswa sebagai "penebak". Guru menginformasikan bahwa dari sebuah kotak yang berisi kelereng telah diambil beberapa kelereng. Guru menyebutkan jumlah kelereng yang diambil dan besar pecahan yang menyatakan bagian kelereng yang diambil dari keseluruhan kelereng dalam kotak tersebut. Siswa diberi kesempatan untuk memikirkan dan menebak, berapa jumlah kelereng dalam kotak tersebut sebelumnya. Jika siswa dapat menjawab dengan benar, maka pertanyaan dilanjutkan lagi untuk jumlah kelereng dan pecahan yang lain. Pertanyaan dimulai dengan pecahan yang mudah, kemudian agar lebih menantang maka pecahan yang diberikan dapat juga dinyatakan dengan pecahan yang senilai. Situasi ini juga dimaksudkan agar siswa mengingat kembali tentang pecahan senilai.
\end{abstract}

\section{Pertemuan Kedua}

\section{Situasi tiga}

Situasi ini dirancang untuk siswa mengingat dan memahami pecahan senilai. 
Aksi :

Terdapat 4 kotak yaitu A, B, C, dan D, dimana masing-masing berisi kelereng yang sama jumlahnya. Seseorang melakukan pengambilan beberapa kelereng dari kotak-kotak tersebut. Kotak A diambil $\frac{1}{5}$ bagian, kotak B diambil $\frac{2}{10}$, dan kotak C diambil $\frac{3}{15}$ bagian. Pikirkan dan diskusikan pertanyaan berikut:

a. Kotak manakah yang isinya (kelereng) diambil paling banyak?

b. Adakah kotak yang isinya diambil sama banyak dengan kotak yang lain?

c. Jika dari kotak D akan diambil kelereng yang sama jumlahnya dengan salah satu dari ketiga kotak yang lain, nyatakanlah jumlah pengambilan yang sama itu dalam bentuk pecahan yang berbeda.

\section{Situasi Empat}

Aksi :

\section{PERMAINAN MENGURUTKAN PECAHAN}

Permainan dilakukan dalam kelompok yang terdiri dari 4 orang, dimana masing-masing anggota kelompok diberi kesempatan untuk memikirkan sebuah pecahan dan menuliskannya pada secarik kertas. Langkah-langkah permainan sebagai berikut:

a. Setiap anggota kelompok menuliskan satu pecahan biasa, dengan syarat bahwa pembilang pecahan tidak lebih dari penyebutnya.

b. Pecahan masing-masing anggota kelompok dikumpulkan, kemudian diurutkan dari yang terkecil. Catatlah bagaimana cara kamu mengurutkan pecahan tersebut

c. Tentukan pemenangnya, yaitu anggota kelompok yang pecahannya mendapat urutan terbesar.

Jika tersedia waktu yang cukup, permainan dapat dilanjutkan dengan membandingkan pecahan terbesar dari setiap kelompok dalam kelas, sehingga didapatkan pecahan terbesar dari semua kelompok dan kelompok tersebut menjadi juara kelas.

\section{Pertemuan Ketiga}

\section{Situasi Lima}

Pada situasi ini akan dilakukan percobaan menemukan hubungan yang menjelaskan tentang penjumlahan pecahan

\section{Aksi :}

Setiap kelompok diberi satu kotak yang berisi sejumlah kelereng. Siswa diminta untuk melakukan pengambilan sebanyak dua kali dengan jumlah yang tidak ditentukan, kemudian menyatakan masing-masing jumlah yang diambil itu dengan pecahan yang sesuai. Hasil pengambilan tersebut kemudian digabungkan dan hasil penggabungannya dinyatakan dalam bentuk pecahan. Siswa kemudian diminta untuk menjelaskan hubungan antara kedua pecahan yang pertama dengan pecahan hasil penggabungannya.

\section{Situasi Enam}

Desain situasi ini tidak jauh berbeda dengan pada situasi lima. Desain situasi enam adalah sebagai berikut :

Aksi :

Setiap kelompok diberi satu kotak yang berisi sejumlah kelereng. Siswa diminta untuk melakukan pengambilan sebanyak dua kali dengan jumlah yang tidak ditentukan. Pengambilan pertama dilakukan seperti biasa (dari dalam kotak) sedangkan pengambilan kedua dilakukan dari kelereng yang diambil pertama. Jumlah pengambilan pertama dan kedua dinyatakan dalam bentuk pecahan, kemudian dibandingkan dengan sisa pengambilan pertama. Siswa kemudian diminta untuk menjelaskan hubungan antara kedua pecahan yang menyatakan jumlah pengambilan pertama dan kedua dengan pecahan yang menyatakan sisa pengambilan pertama. 


\title{
4. Pertemuan Keempat
}

\section{Situasi Tujuh}

Situasi ini diarahkan untuk menemukan hubungan yang menjelaskan tentang perkalian pecahan.

\begin{abstract}
Aksi :
Sebuah perusahaan memberikan jatah air minum kepada karyawannya dalam bentuk air mineral dalam kemasan gelas. Air mineral tersebut dikemas dalam satu karton yang berisi 48 gelas. Dalam satu hari, satu karyawan diberi jatah 2 kali dengan satu kali pengambilan tidak lebih dari $\frac{1}{8}$ bagian dari isi karton. Pada suatu hari, karyawan A mengambil semua jatahnya, karyawan B mengambil hanya satu kali, karyawan $\mathrm{C}$ satu kali mengambil dan hanya $\frac{1}{3}$ dari jatah sekali pengambilan, dan karyawan D juga hanya satu kali mengambil $\frac{1}{2}$ dari jatah sekali pengambilan. Catatlah pengambilan dari masing-masing karyawan dan diskusikanlah pertanyaan berikut:

a. Nyatakanlah jumlah pengambilan satiap karyawan pada hari itu, dalam bentuk pecahan yang menyatakan bagian dari isi karton.

b. Dapatkan jumlah pengambilan masing-masing karyawan ditentukan dengan perkalian pecahan? jika dapat, tunjukkanlah.

c. Jika setiap karyawan mengambil jatah yang sama setiap hari, hitunglah banyaknya pengambilan untuk masing-masing karyawan selama 6 hari.?
\end{abstract}

\section{Situasi Delapan}

Situasi ini diarahkan untuk menemukan hubungan yang menjelaskan tentang pembagan pecahan.

Aksi :

Permasalahan berikut masih berkaitan dengan permasalahan sebelumnya tentang pembagian jatah air minum. Untuk memudahkan pembagian, petugas Logistik ingin mengemas ulang air mineral tersebut kedalam kemasan yang lebih kecil. Kemasan warna putih berisi $\frac{1}{8}$ karton dan kemasan warna merah berisi $\frac{1}{4}$ karton. Dari satu karton dibagi sama untuk mengisi kedua jenis kemasan tersebut. Berapakan kemasan warna putih dan merah yang dapat dihasilkan dari 1 karton air mineral tersebut?

\section{Pertemuan Kelima}

\section{Situasi Sembilan}

Aksi 1:

Kita telah bersama belajar pada pertemuan pertama tentang arti dan nilai dari sebuah pecahan biasa. Dapatkah kamu menjelaskan arti dari $\frac{2}{3}$ ?

\section{Aksi 2 :}

Pada contoh pengambilan kelereng dari dalam sebuah kotak, apa yang akan terjadi jika Pecahan yang menyatakan banyaknya pengambilan itu :

a. Memiliki pembilang yang sama dengan penyebutnya?

b. Memiliki pembilang lebih dari penyebutnya?

c. Bagaimana kamu menuliskan pecahan-pecahan tersebut?

\section{Situasi Sepuluh}

Aksi :

Diberikan beberapa pecahan sebagai berikut: $\frac{1}{4}, \frac{8}{5}, \frac{3}{8}, \frac{2}{3}$

a. Dapatkah pecahan-pecahan tersebut dinyatakan dengan pecahan senilai yang berpenyebut 10, 100, atau 1000 ?

b. Bagaimana menyatakan pecahan tersebut dalam bentuk desimal?

\section{Pertemuan keenam}

\section{Situasi Sebelas}

Aksi :

Disediakan kartu pecahan yang ditulis dalam bentuk pecahan biasa, campuran, desimal dan persen. Setiap kelompok siswa mengambil secara acak satu kartu dari masing-masing bentuk 
pecahan. Setiap kelompok diberi tugas untuk mengurutkan pecahan-pacahan yang mereka dapatkan dari yang terkecil kemudian mengambarnya dalam sebuah garis bilangan.

\section{Situasi Duabelas}

Aksi :

Siswa diajak untuk mengingat kembali masalah pengambilan kelereng dari dalam kotak. Misalkan terdapat tiga kotak yang masing-masing berisi 8 kelereng. Andi melakukan pengambilan kelereng sebanyak dua kali. Pengambilan pertama sebanyak 13 kelereng dan pengambilan kedua sebanyak 6 kelereng.

a. Nyatakanlah banyaknya tiap pengambilan itu dengan pecahan, dan tentukanlah pula jumlah pengambilan seluruhnya dalam bentuk pecahan.

b. Dapatkah solusi dari pertanyaan 1) dilakukan dengan pecahan bentuk yang lain? Jika dapat, tunjukkanlah.

c. Jika pengambilan pertama dikurangi pengambilan kedua, berapakah sisa pengambilan pertama? Nyatakanlah dalam bentuk pecahan.

d. Dapatkah solusi dari pertanyaan 3) dilakukan dengan pecahan bentuk yang lain? Jika dapat, tunjukkanlah.

\section{Pertemuan ketujuh}

\section{Situasi Tigabelas}

Aksi :

Pada pertemuan sebelumnya telah kita pelajari perkalian dan pembagian pecahan. sebagai contoh

a. $\frac{6}{5} \times \frac{9}{4}=\frac{54}{20}$

b. $\frac{7}{4}: \frac{14}{5}=\frac{35}{56}$

Jika pecahan pada kedua contoh diatas dinyatakan dalam bentuk pecahan campuran atau pecahan desimal, bagaimana cara kamu menyelesaikannya? Tunjukkanlah.

\section{Simpulan dan Rekomendasi}

\subsection{Simpulan}

Berdasarkan hasil penelitian dan pembahasan diperoleh kesimpulan sebagai berikut :

1. Hambatan belajar (learning obstacles) yang dialami siswa dalam mempelajari materi pecahan adalah epistemological obstacles dan didactical obstacles. Epistemological obstacles yaitu generalisasi konsep bilangan cacah dan bilangan bulat terhadap pecahan, dan didactical obstacles yaitu penekanan pembelajaran pada aspek prosedural sehingga pemahaman siswa terbatas pada cara melakukan operasi hitung pecahan. Dalam penelitian ini tidak teridentifikasi adanya ontogenical obstacles.

2. Desain didaktis hipotetik mengalami beberapa revisi, diantaranya adalah beberapa pernyataan pada situasi aksi dan penambahan perkiraan waktu. Beberapa respon yang tidak terduga sebelumnya, yang merupakan catatan selama implementasi telah ditambahkan dalam desain didaktis revisi. Desain didaktis revisi terdiri dari 13 situasi didaktis dalam 7 pertemuan

\subsection{Rekomendasi}

Beberapa rekomendasi yang dapat dijadikan pertimbangan, khususnya bagi yang akan menggunakan desain didaktis hasil penelitian ini dalam pembelajaran materi pecahan di SMP, maupun menjadikan sebagai referensi penelitian selanjutnya adalah sebagai berikut :

1. Pada subyek yang lain, masih memungkinkan teridentifikasi karakteristik learning obstacles yang lain. Untuk itu bagi peneliti selanjutnya dapat melanjutkan untuk mengidentifikasi tipe learning obstacles yang lain, termasuk kemungkinan adanya ontogenical obstacles yang dialami siswa terkait materi pecahan.

2. Desain didaktis yang dihasilkan dalam penelitian ini disesuaikan dengan karakteristik subyek penelitian dan dugaan lintasan belajar siswa yang dimulai dari pengetahuan prasyarat dan konsep awal pecahan. Hal tersebut berbeda dengan tingkat penguasaan kompetensi yang disyaratkan dalam kurikulum untuk siswa SMP, sehingga penyajiannya akan menyerap lebih banyak waktu dari alokasi waktu yang diperkirakan dalam kurikulum. Guru dapat melakukan penyesuaian 
dengan alokasi waktu yang tersedia, dengan penekanan pembelajaran pada penerapan pecahan dalam masalah kontekstual.

\section{Daftar Pustaka}

1. Brousseau, G., 1997, Theory of Didactical Situations in Mathematics, New York: Kluwer Academic Publishers.

2. Fazio, L., Siegler, R., 2010, Teaching Fractions, France: UNESCO (Gonnet Imprimeur, 01300 Belley).

3. Noura, K., 2009, Understanding Fractions, www.mav.vic.edu.au/files/ conferences/2009, Diakses tanggal 14 Desember 2014.

4. Putra, N., 2012, Metode Penelitian Kualitatif Pendidikan, Jakarta: Rajawali Pers.

5. Suryadi, D., 2010. Menciptakan Proses Belajar Aktif: Kajian dari Sudut Pandang Teori Belajar dan Teori Didaktik, Makalah pada Seminar Nasional Pendidikan Matematika UNP, Tidak diterbitkan.

6. Suryana, Y., dkk., 2012, Desain Didaktis Pengenalan Konsep Pecahan Sederhana pada Pembelajaran Matematika untuk Siswa Kelas III SD, Prosiding Seminar Matematika dan Pendidikan Matematika Sekolah, FMIPA UNY, Yogyakarta, 412-426.

7. Sugiyono, 2013, Metode Penelitian Kuantitatif, Kulitatif, dan R\&D, Bandung: Alfabeta. 
Jaky Jerson Palpialy \& Elah Nurlaelah/JMI Vol. 11 No. 2, Oktober 2015 pp. 127 - 136 